\title{
IDENTIFICATION OF THE PAINTING MATERIALS OF A UNIQUE EASEL PAINTING BY MAHMOUD SA'ID
}

\author{
Elsayed, Y. \\ Conservation dept., Faculty of Archaeology, Damietta Univ., Damietta, Egypt \\ E-mail: yea00@fayoum.edu.eg
}

\begin{abstract}
The present study aims at examining a unique easel painting by the well-known Egyptian painter, Mahmoud Sa'id. It was painted over four years and displayed at the Agricultural Museum in Egypt. It experienced many deterioration phenomena. The study utilized some non-destructive and non-invasive analytical techniques, i.e. MA-XRF, SEM-EDX, ATR-FTIR, and GC-FID in addition to XRD and SM. Due to the case-study painting multilayers technique, the results of MA-XRF and EDX mapping and XRD patterns revealed using Ultramarine $(\mathrm{Na}, \mathrm{Ca})_{8}$ $\left(\mathrm{AlSiO}_{4}\right)_{6}\left(\mathrm{SO}_{4}, \mathrm{~S}, \mathrm{Cl}\right)_{2}$, yellow ochre $\left(\mathrm{Fe}_{2} \mathrm{O}_{3} . \mathrm{H}_{2} \mathrm{O}\right)$, red ochre $\left(\mathrm{Fe}_{2} \mathrm{O}_{3}\right)$, and a mixture of graphite (C) and bone black $\left(\mathrm{C}, \mathrm{Ca}_{5}(\mathrm{OH})\left(\mathrm{PO}_{4}\right)_{3}\right)$ as a coloring pigments in the blue, yellow, reddish brown and black samples, respectively. Moreover, Barite $\left(\mathrm{BaSO}_{4}\right)$ and Zincite $(\mathrm{ZnO})$ were used in the ground layer with Hydrocerussite $\left(\mathrm{Pb}_{3}\left(\mathrm{CO}_{3}\right)_{2}(\mathrm{OH})_{2}\right)$ and (Sphalerite ( $\left.\mathrm{ZnS}\right)$ in lightening colors. Linseed oil was asserted as the pigment binding media, while the binding media of the ground layer was not confirmed. Furthermore, fragility, brittleness, cleavages, peeling, cracks, macro cracks, stains, and ancient fault restoration were detected in the casestudy painting. Accordingly, it urgently requires treatment.
\end{abstract}

Keywords: Painting, MA-XRF, ATR-FTIR, SEM-EDX, GC

\section{Introduction}

Easel paintings are usually created on canvas supports made of natural organic fibers such as linen, cotton, and hemp [1,2]. The canvas is usually coated with a ground layer including inorganic white materials, such as calcium carbonate, zinc oxide, lead carbonate, barium sulfate...etc. [3,4]. It also include and organic binders, e.g. animal glue, fish glue, and casein glue [5, $6]$. The white ground layer is painted using inorganic pigments such as azurite, malachite, zincite, red and yellow ochre, naples yellow, vermilion, ultramarine, verdigris, cobalt blue, bone black...etc. [7,8] and/ or organic dyes such as madder, alizarin, indigo, Indian yellow, luteolin, quercetin etc. mixed with drying oil such as linseed oil, poppy seed oil, safflower oil...etc. Then, it may be covered by a varnish layer [9-11]. A considerable number of analytical methods have been employed to identify organic and inorganic painting materials. For example, the X-ray diffraction (XRD) and Macroscopic X-ray diffraction (MA-XRD) are used to identify inorganic chemical compounds in a destructive and non-destructive way. Scanning Electron Microscope with Energy Dispersive X-ray Spectroscopy (SEM-EDX) and X-ray Fluorescence (XRF) are used in the identification of the chemical elements in painting materials $[12,13]$. Moreover, the Macroscopic X-ray Fluorescence (MA-XRF) is one of the most efficient 
and non-invasive techniques for mapping the elemental distribution in painted objects. It can visualize the entire painted surface and subsurface layers $[14,15]$. Hence, it offers many details about the process of painting creation and the technique of artists [16]. Some separation and spectroscopic techniques, including Chromatography techniques, e.g. Mass Spectroscopy (MS), Raman Spectroscopy (RS), Fourier Transform Infrared Spectroscopy (FTIR) are successfully utilized to provide detailed information about the organic and inorg-

\section{Materials and Methods}

\subsection{The case study painting}

The case study is a historical oil painting on canvas, named "Lady on a Roof", fig. (1-a,b), exhibited at the Egyptian Agricultural Museum in Giza. It is signed by the well-known Egyptian painter, Mahmoud Sa'id (one of the pioneer Egyptian painters who established the modern Egyptian Painting School. While traveling to Europe, Sa'id studied the art of painting at the Académie Julian in Paris - France. He had his own and distinct painting technique from 1919 to 1964 (his death). In the beginning, he was influenced by impressionism. Later, he abandoned all artistic techniques to his own one affected by a mixture of the European legacy of art and the Ancient Egyptian art [23-25]. The painting measures $110 \times 110 \mathrm{~cm}$ and dates back to 1928-1932 (as the painter inserted beside his signature in the lower right corner), fig. (1-c). It isn't accurately known why it took four years to be implemented. Thus, it is worthy of research to detect the impact of the four-year period on the case-study painting, the painting layers

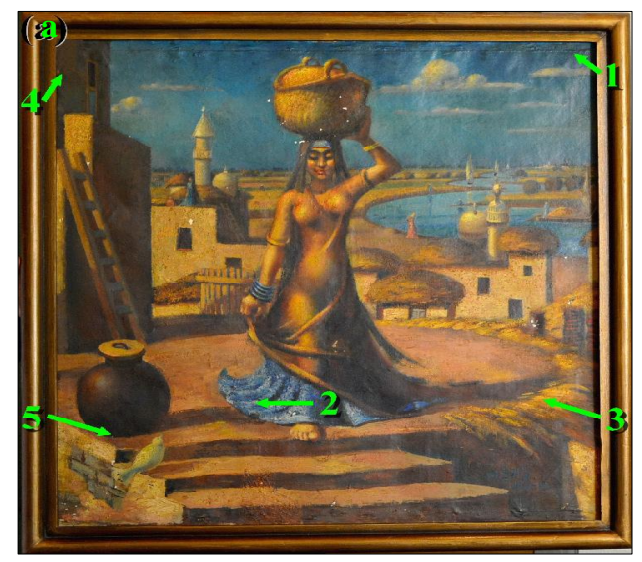

anic materials, either natural or synthetic, in the painted objects [17-20]. Although these techniques can reveal both the chemical composition and characterization of the investigated painting materials, most of them, as well as others require a destructive or non-destructive sampling or hard and time-consuming sample preparation. Their continuous development has resulted in some non-invasive and higher performance instruments [21,22].

it has, and the elemental mapping of painting materials according to the signals of the acquired elements. Artistically, the painting shows a standing Egyptian peasant lady on a roof, carrying a twinhand basket. The background is a landscape of the sky, small houses, mosques, and a canal. The features are affected by Akhenaten style, especially in the lady's face, hands and warm colors. In addition to the symbol of woman fertility with simplicity, it is coated with varnish and framed with a gilded simple wooden frame. The visual inspection of the object reveals that it consists of different pigment layers and a white ground layer, fig. (1-d). It has experienced many deterioration phenomena, e.g. cracks and macro-cracks, fig. (1-e), peeling and cleavage of the paint layer in some area, fig. (1-f), stains and dirt on the painting verso, fig. (1-g), ancient faulty inpaintings, fig. (1-h,i), and ancient faulty patching, fig. (2-j).

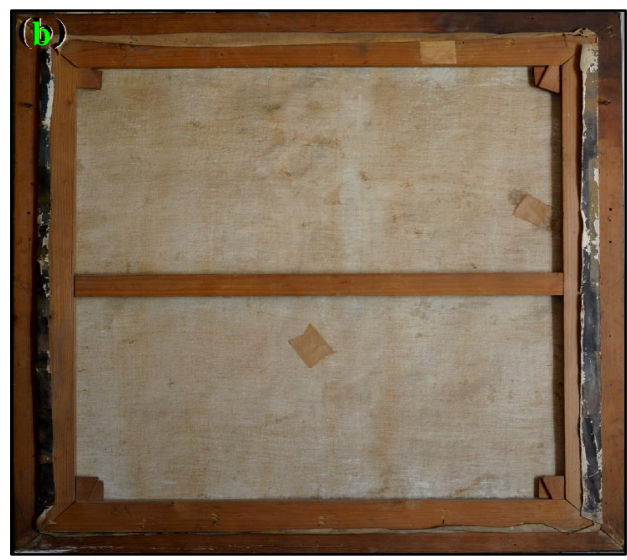



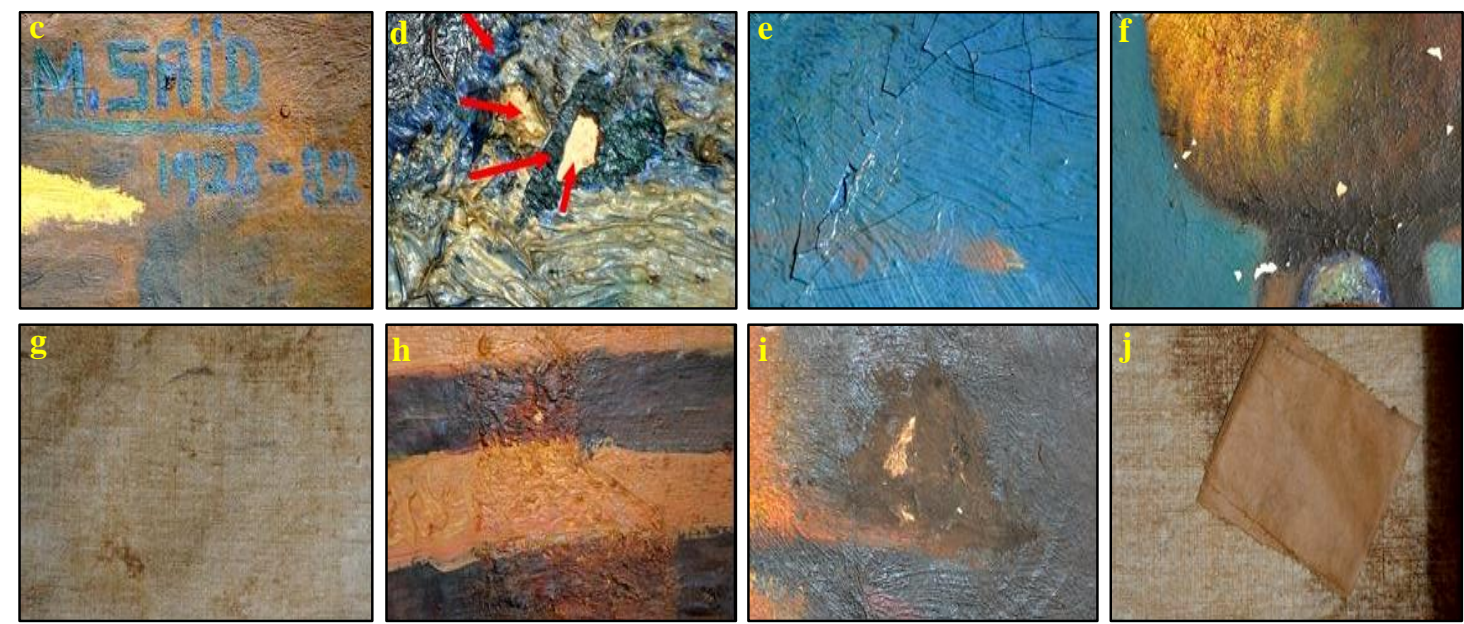

Figure (1) Shows some details of the case-study $\underline{\mathbf{a}}$. the front, $\underline{\mathbf{b}}$. the verso, $\underline{\mathbf{c}}$. signature of the painter Mahmoud Sa'id and date front, $\underline{\mathbf{d}}$. multilayers used technique, $\underline{\mathbf{f}}$. cracks, g. peeling and cleavage of paint layer, e. stains and dirts, $\underline{\mathbf{h}}$. \& $\underline{\mathbf{i}}$. wrong inpainting, $\mathbf{j}$. wrong patching

\subsection{Sampling}

Because the case-study painting is exhibited at the Egyptian Agricultural Museum in Giza, it is impossible to be moved to anywhere else for investigation in a non-invasive way. Thus, four macro-samples (blue, yellow, reddish brown and black) were collected to be directly investigated without preparation.

They were carefully taken from edges of the painted canvas under the wooden frame, as pointed by the green arrows fig. (1-a). To be utilized in many investigations and analyses, the collected macro-samples were initially investigated by the non-destructive methods, then by the XRD as a destructive method.

\subsection{Macro X-ray fluorescence (MA-XRF)}

Because of the possibility of MAXRF scanning to collect spectra and maps from the surface of inorganic object without sampling [26,27], the study employed the MA-XRF scanning system (M6 Jetstream, Bruker Nano $\mathrm{GmbH}$, Berlin, Germany) based on the Center for Modern Interdisciplinary Technologies, ICNT, Nicolaus Copernicus University UMK in Toruń, Poland. An $\mathrm{X}$-ray tube with a rhodium target at 50 $\mathrm{kV}$ was used; an anode current of 600

$\mu \mathrm{A}$, no filters and a $30 \mathrm{~mm} 2 \mathrm{SDD}$ with zirconium window were utilized. A range of $\mathrm{X}$-ray energy from 0.35 $\mathrm{keV}$ to $40 \mathrm{keV}$ was covered, the most important peaks were obtained from $\sim 2$ $\mathrm{keV}$ to $\sim 18 \mathrm{keV}$. The scanning process was conducted in air pressure of 1055 mbar and the time of acquisition was $40 \mathrm{~ms} /$ pixel during the data collection of the four examined samples.

\subsection{Scanning electron microscopy with EDX (SEM-EDX)}

Due to the less sensitivity of MA-XRF for the low-Z elements such as $\mathrm{Mg}, \mathrm{Al}$, and $\mathrm{Si}[16,28]$, the use of other techniques with higher sensitivity such as SEM-EDX is generally recommended to detect a wider range of probable chemical elements of different inorganic pigments and other compounds in the painting layers jointly with other techniques like XRD [29]. The study used SEM-EDX (ZEISS LEO 1430VP, Bruker, Germany at the Faculty of Chemistry,
UMK in Torun, Poland). SEM-EDX mapping and analysis of the samples were carried out in low vacuum mode (100$120 \mathrm{~Pa}$ ), at $15-20 \mathrm{kV}$ acceleration voltage and backscattered electron detection. The samples were scanned with a focused electron beam and delivered images with information about the samples' composition and topography in highresolution information and superior contrast. 


\subsection{X-ray diffraction (XRD)}

$\mathrm{XRD}$ analysis was conducted using a X-ray diffractometer system, PANalytical, X'pert PRO MPD, powered by a Philips PW3040/60 X-ray generator, Netherlands. The configuration were $\mathrm{Cu}$ tube anode, K-alpha1 $[\AA]$ 1.54060, start position [ ${ }^{\circ} \mathrm{Th}$.] 8.0066 , end position

\subsection{Stereo microscope (SM)}

The study used an SM (SMZ800, Nikon, at the Faculty of Fine Arts, UMK in Torun, Poland) to identify the painting layers based on cross-sectioned macro-samples. Some macro-samples were prepared using the polyester resin,

\subsection{Attenuated total reflectance opy (ATR-FTIR)}

For the identification of the binding media and pigments in the painting, the study used the FTIR in ATR mode (Spotlight 200i FT-IR Microscopy System, Perkin Elmer) in the Josef Bank

\subsection{Gas chromatography-flame ionization detector (GC-FID)}

A gas chromatograph (Agilent Technologies Inc., 6890 series, CA, USA; DB23 capillary column, measures $60 \mathrm{~m}$ $\mathrm{X} 0.32 \mathrm{~mm}$ X $0.25 \mu \mathrm{m}$ ) equipped with a split injector and a flame ionization detector (FID), at the Agriculture Research Center in Cairo was used to identify the oil type in the samples. About $0.1 \mathrm{mg}$ of each sample was dissolved in a $30 \mathrm{ml}$ mixture of toluene:

\section{Results}

\subsection{MA-XRF}

The results of macro-samples scanned by MA-XRF showed nine elements: Calcium (Ca), Chromium $(\mathrm{Cr})$, Iron $(\mathrm{Fe})$, Zinc (Zn), Barium $(\mathrm{Ba})$, Lead $(\mathrm{Pb})$, Strontium (Sr), as well as very low signals of Potassium


[ $\left.{ }^{\circ} \mathrm{Th}.\right]$ 70.0116, scan type continuous, PSD mode scanning, PSD length $\left[{ }^{\circ} 2 \mathrm{Th}\right.$.] 3.35 , generator settings $40 \mathrm{~mA}, 45$ $\mathrm{kV}$, diffractometer type 3195 , at The Grand Egyptian Museum-Conservation Center (GEM-CC).

then ground and polished by polisher/ grinder with silicon carbide waterproof abrasive papers. Other samples were investigated directly without molding resin.

\section{fourier-transform infrared microsc-}

Laboratories, University of Lincoln, UK). The spectra were acquired between $4000^{-1}$ and $400 \mathrm{~cm}^{-1}$ with 64 acquisitions and $4 \mathrm{~cm}^{-1}$ resolution.

methanol (2:1), then evaporated, and methylated by a mixture of methanol, gasoline, and sulphuric acid (84:10: $4 \%$ ) respectively, at $150{ }^{\circ} \mathrm{C}$ for $5 \mathrm{~min}$, then $170{ }^{\circ} \mathrm{C}$ for $3 \mathrm{~min}$. The floating liquid was moved to a vial with conical inserts for injection into the GC. The detector was set at $270 \mathrm{ml} / \mathrm{min}$ airflow, $40 \mathrm{ml} / \mathrm{min}$ hydrogen flow and $25 \mathrm{ml} / \mathrm{min}$ nitrogen [30,31].

$(\mathrm{K})$ and Copper $(\mathrm{Cu})$. Moreover, the elemental distribution mapping of the different elements is displayed in figs. ( 2 -a,b,c,d,e,f,g,h), in addition, the spectra of the same elements are shown in fig. (2-i)
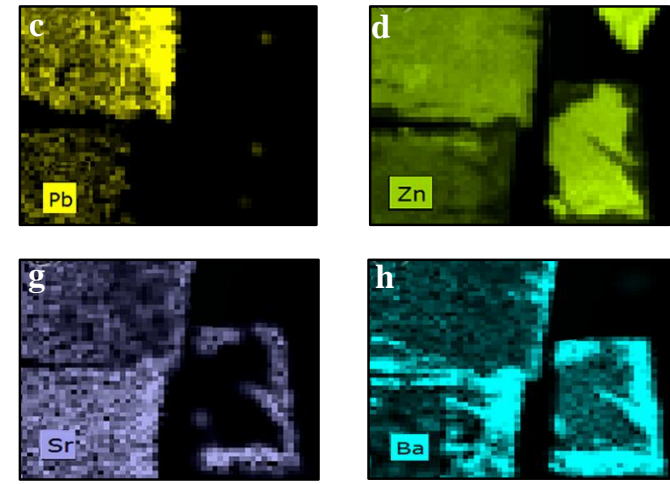


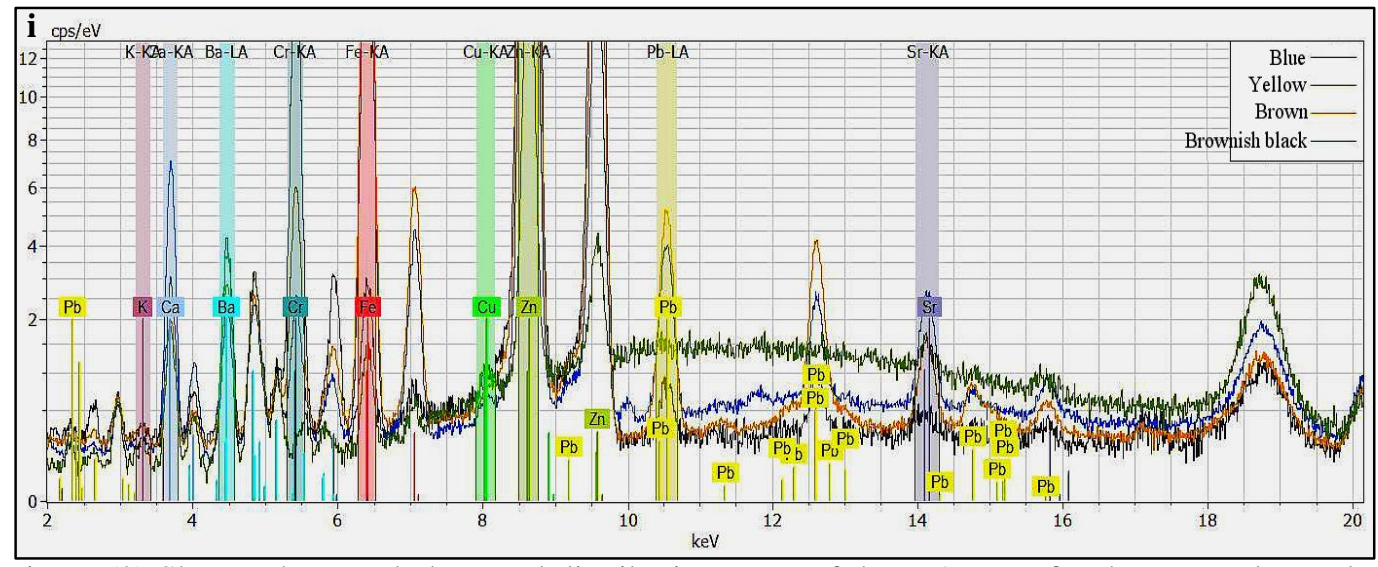

Figure (2) Shows photo and elemental distribution maps of the MA-XRF for the scanned samples from the case-study painting; $\underline{\mathbf{a}}$. a normal photo, $\underline{\mathbf{b}}$. Iron map $(\mathrm{Fe})$, $\underline{\mathbf{c}}$. Lead map $(\mathrm{Pb})$, $\underline{\mathbf{d}}$. Zinc map (Zn), e. Chromium map (Cr), $\underline{\mathbf{f}}$. Calcium map (Ca), g. Strontium map (Sr), $\underline{\mathbf{h}}$. Barium map (Ba), i. spectra of the MA-XRF scanning for the four samples from the case-study painting showing the presence of Iron $(\mathrm{Fe}-\mathrm{K} \alpha)$, Lead $(\mathrm{Pb}-\mathrm{L} \alpha)$, Zinc ( $\mathrm{Zn}$ $\mathrm{K} \alpha)$, Chromium $(\mathrm{Cr}-\mathrm{K} \alpha)$, Calcium $(\mathrm{Ca}-\mathrm{K} \alpha)$, Strontium $(\mathrm{Sr}-\mathrm{K} \alpha)$, Barium (Ba-L $\alpha)$, Potassium $(\mathrm{K}-\mathrm{K} \alpha)$ and Copper $(\mathrm{Cu}-\mathrm{K} \alpha)$

\subsection{SEM-EDX}

The SEM micrographs of the investigated samples in different magnifications indicated that the canvas is made of linen threads, glued and covered with ground and paint layers. It is very brittle and polluted by some dirt, fig. (3-a). The paint layer has experienced high fragility and decay until the surface layer is almost turned powder in some spots. In other investi-

gated spots, the paint layer is cracked, macro-cracked, cleaved, or completely peeled away, fig. (3-b, c). EDX spectra and maps of the investigated blue sample, fig. (4-a), yellow sample, fig. (4-b), reddish brown sample, fig. (4-c), and black sample, fig. (4-d) are composed of many elements: $\mathrm{C}, \mathrm{O}, \mathrm{Mg}, \mathrm{Al}, \mathrm{Si}, \mathrm{P}$, $\mathrm{S}, \mathrm{Cl}, \mathrm{K}, \mathrm{Ca}, \mathrm{Cr}, \mathrm{Fe}, \mathrm{Zn}, \mathrm{Sr}, \mathrm{Cd}, \mathrm{Ba}$, and $\mathrm{Pb}$ as shown in tab. (1).
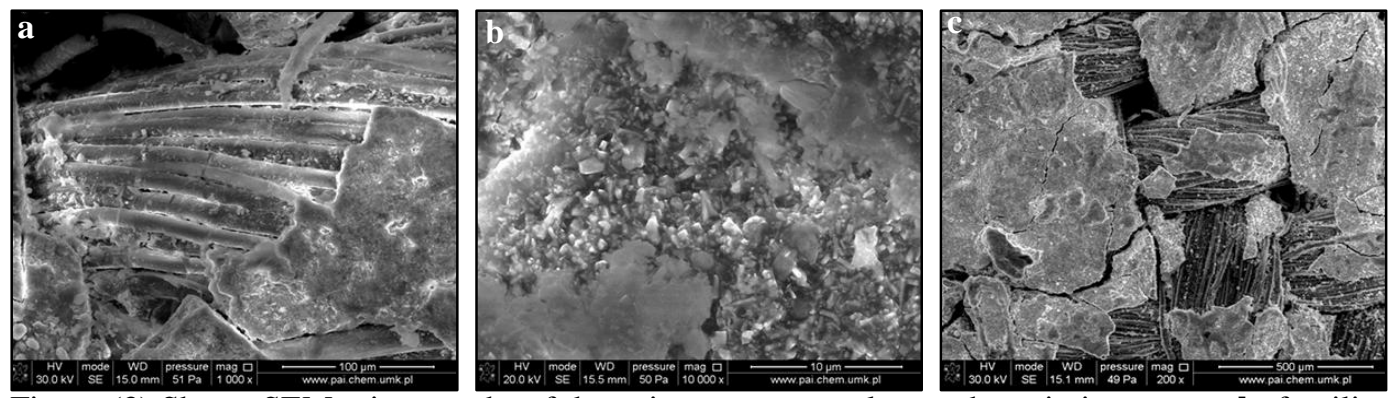

Figure (3) Shows SEM micrographs of the paint macro-samples; $\underline{\mathbf{a}}$. the painting canvas $\underline{\mathbf{b}}$. fragility and decay in paint layer, $\underline{\mathbf{c}}$. cracks, macro-cracks, cleavage and peeling of the paint layer
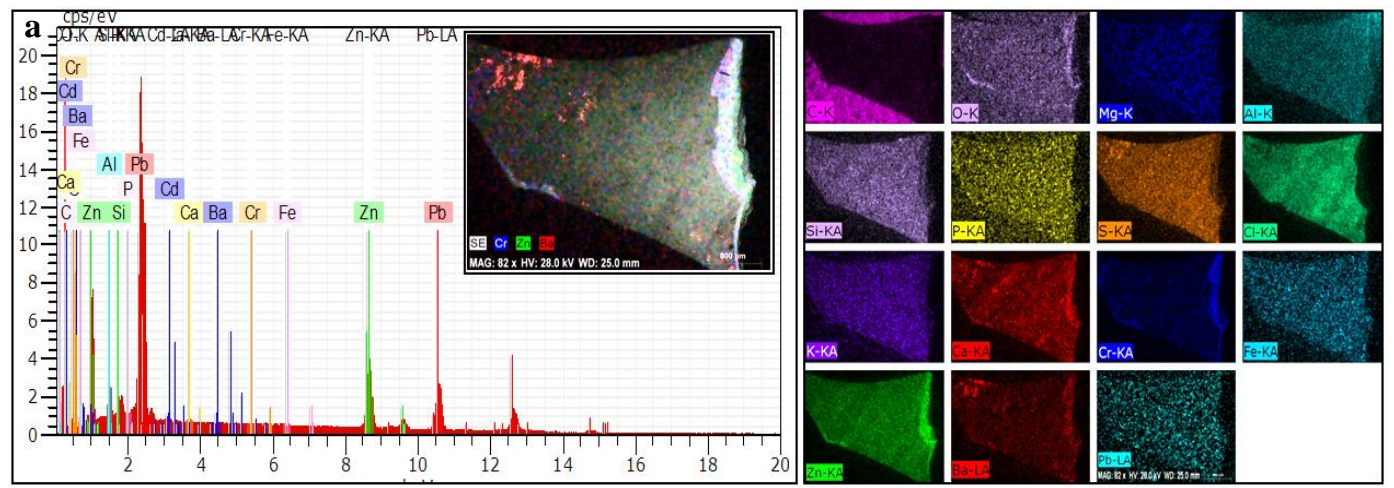

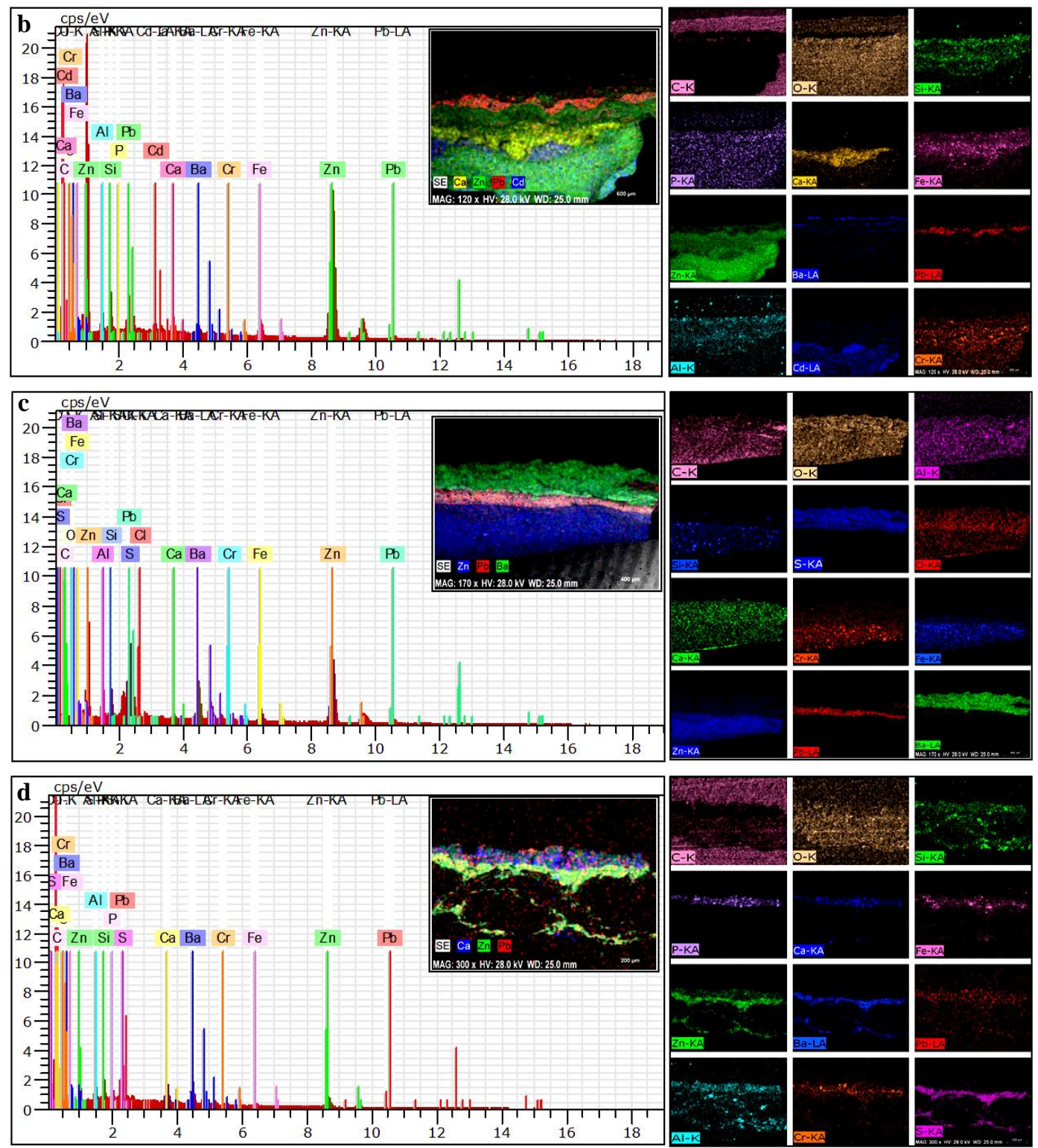

Figure (4) Shows results of EDX maps and spectra of macro-sample $\underline{\mathbf{a}}$. blue, $\underline{\mathbf{b}}$. yellow, $\underline{\mathbf{c}}$. reddish, $\underline{\mathbf{d}}$. black

Table (1) the scanned samples and the \% of EDX detected elements

\begin{tabular}{|c|c|c|c|c|c|c|c|c|c|c|c|c|c|c|c|c|c|}
\hline \multirow[t]{2}{*}{ Sample } & \multicolumn{17}{|c|}{ \% EDX detected elements } \\
\hline & $C$ & $O$ & $M g$ & $A l$ & $S i$ & $P$ & $S$ & $\mathrm{Cl}$ & $K$ & $\mathrm{Ca}$ & $\mathrm{Cr}$ & $F e$ & $Z n$ & $S r$ & $C d$ & $B a$ & $P b$ \\
\hline Blue & 9.8 & 34 & 0.4 & 3.6 & 2.1 & 0.0 & 3.3 & 3.5 & 0.3 & 3.5 & 1.3 & 0.5 & 20 & 1.3 & 0.5 & 4.6 & - \\
\hline Yellow & 14 & 45 & - & 2.5 & 3.2 & - & - & - & - & 1.4 & 0.1 & 2.1 & 24. & - & 0.7 & 5.1 & 3.7 \\
\hline $\begin{array}{l}\text { Reddish- } \\
\text { brown }\end{array}$ & 20 & 63 & 0.3 & 1.4 & 1.1 & 0.8 & 2.6 & 0.2 & 0.1 & 1.6 & 0.4 & 0.6 & 4.3 & - & - & 6.9 & 2.0 \\
\hline black & 19 & 54 & 0.5 & 2.7 & 2.2 & 1.1 & - & 0.4 & 0.4 & 3.3 & 2.1 & 1.2 & 4.6 & - & - & 2.3 & 6.8 \\
\hline
\end{tabular}

\section{3. $X R D$}

XRD results of the four investtigated macro-samples summarized in tab. (2) and shown in fig. (5) reveal that the blue sample contains ultramarine (lazurite) $(\mathrm{Na}, \mathrm{Ca})_{8}\left(\mathrm{AlSiO}_{4}\right)_{6}\left(\mathrm{SO}_{4}, \mathrm{~S}, \mathrm{Cl}\right)_{2}$ as a blue pigment, the yellow sample contains yellow ocher $\left(\mathrm{Fe}_{2} \mathrm{O}_{3} \cdot \mathrm{H}_{2} \mathrm{O}\right)$, the reddish brown sample contains red ocher $\left(\mathrm{Fe}_{2} \mathrm{O}_{3}\right)$. In addition, the black sample contains graphite (C) as a black pigment. Moreover, many white materials, e.g. barite $\left(\mathrm{BaSO}_{4}\right)$, Zincite $(\mathrm{ZnO})$, hydrocerussite $\left(\mathrm{Pb}_{3}\left(\mathrm{CO}_{3}\right)_{2}(\mathrm{OH})_{2}\right)$ and sphalerite $(\mathrm{ZnS})$, and Quartz $\left(\mathrm{SiO}_{2}\right)$, are detected. 
Table (2) the results of XRD analysis for the case-study samples

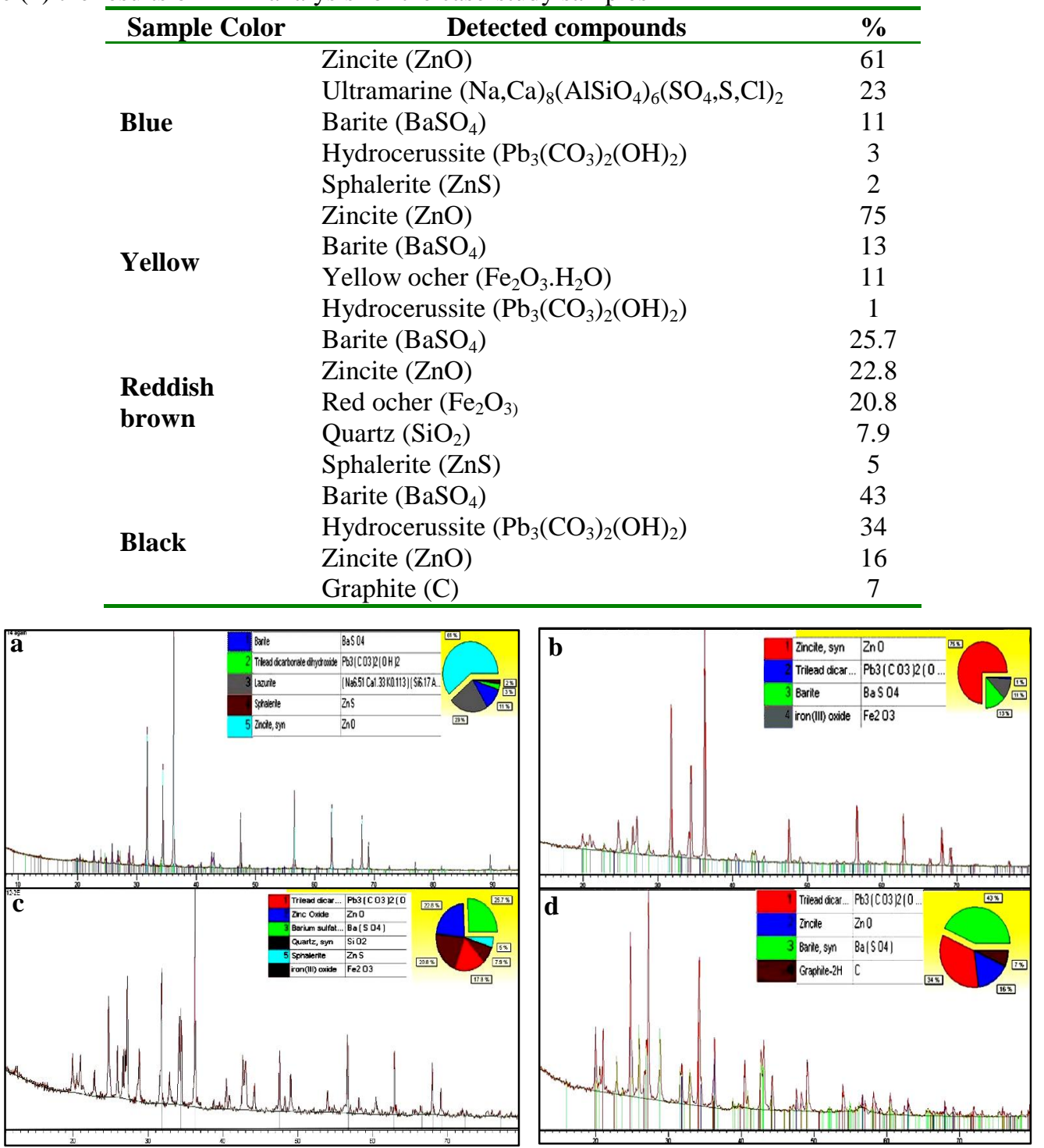

Figure (5) shows the XRD pattern of the investigated macro-samples: $\underline{\mathbf{a}}$. blue, $\underline{\mathbf{b}}$. yellow, $\underline{\mathbf{c} .}$ reddish brown and $\underline{\mathbf{d}}$. black

\subsection{SM}

The SM macrographs of the investigated samples show the multilayers technique of the case-study painting which consists of the canvas, glue layer, white ground layer, and two/three paint layers, fig. (6-a,b,c). The canvas is a plain linen textile weaved in $1 / 1$ technique with a linear density of the threads about 25 . The threads are well-covered by the glue layer
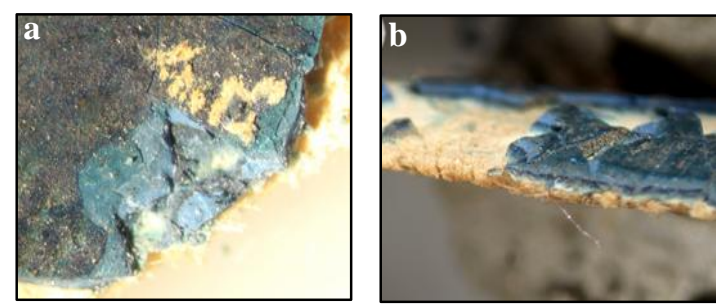

and well-penetrated by the white ground layer, fig. (6-d,e). The yellow sample reveals out multilayers technique and mixtures of pigments in different colors like the greenish, light brown and white, fig. (6-f). The black layer looks attenuated and includes only one pigment layer upon the canvas and a white ground layer, fig. (6-g,h).
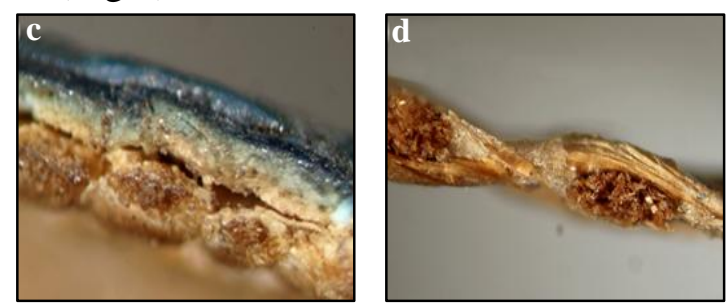



Figure (6) Shows SM results of the paint macro-samples; $\underline{\mathbf{a}}$. and $\underline{\mathbf{b}}$. surface micrographs show the multilayer technique, $\underline{\mathbf{c}}$. cross section micrograph of blue sample, $\underline{\mathbf{d}}$. cross section

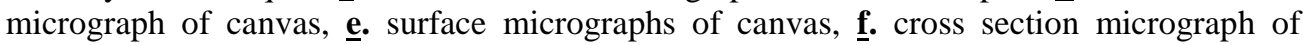
yellow sample, g. cross section micrograph of reddish brown sample, $\underline{\mathbf{h}}$. cross section micrograph of black sample

\subsection{ATR-FTIR Spectroscopy}

Comparing the obtained spectra from the investigated samples by FTIR in ATR mode with the reference spectra of the expected materials, fig. (7), reveals that the binding media is linseed oil and the large band of $\mathrm{C}=\mathrm{O}$ stretching that appeared at $1704 \mathrm{~cm}^{-1}$ and $1740 \mathrm{~cm}^{-1}$ is consistent with the presence of linseed oil and varnish resin. The bands at $721 \mathrm{~cm}^{-1}$, $1095 \mathrm{~cm}^{-1}, 1175 \mathrm{~cm}^{-1}$ and $1245 \mathrm{~cm}^{-1}$ are also assigned to linseed oil, while the bands at $1379 \mathrm{~cm}^{-1}, 1459 \mathrm{~cm}^{-1}, 2856 \mathrm{~cm}^{-1}$

and $2929 \mathrm{~cm}^{-1}$ are assigned to linseed oil and resin (dammar or mastic) [32]. Regarding the coloring pigments, the blue sample bands characterize ultramarine, hydro-cerussite and linseed oil, fig. (7-a). The yellow sample contains yellow ochre and linseed oil, fig. (7-b), while the reddish brown sample contains red ochre and linseed oil, fig. (7-c). moreover, the black sample contains bone black, mastic resin and linseed oil, fig. (7-d).

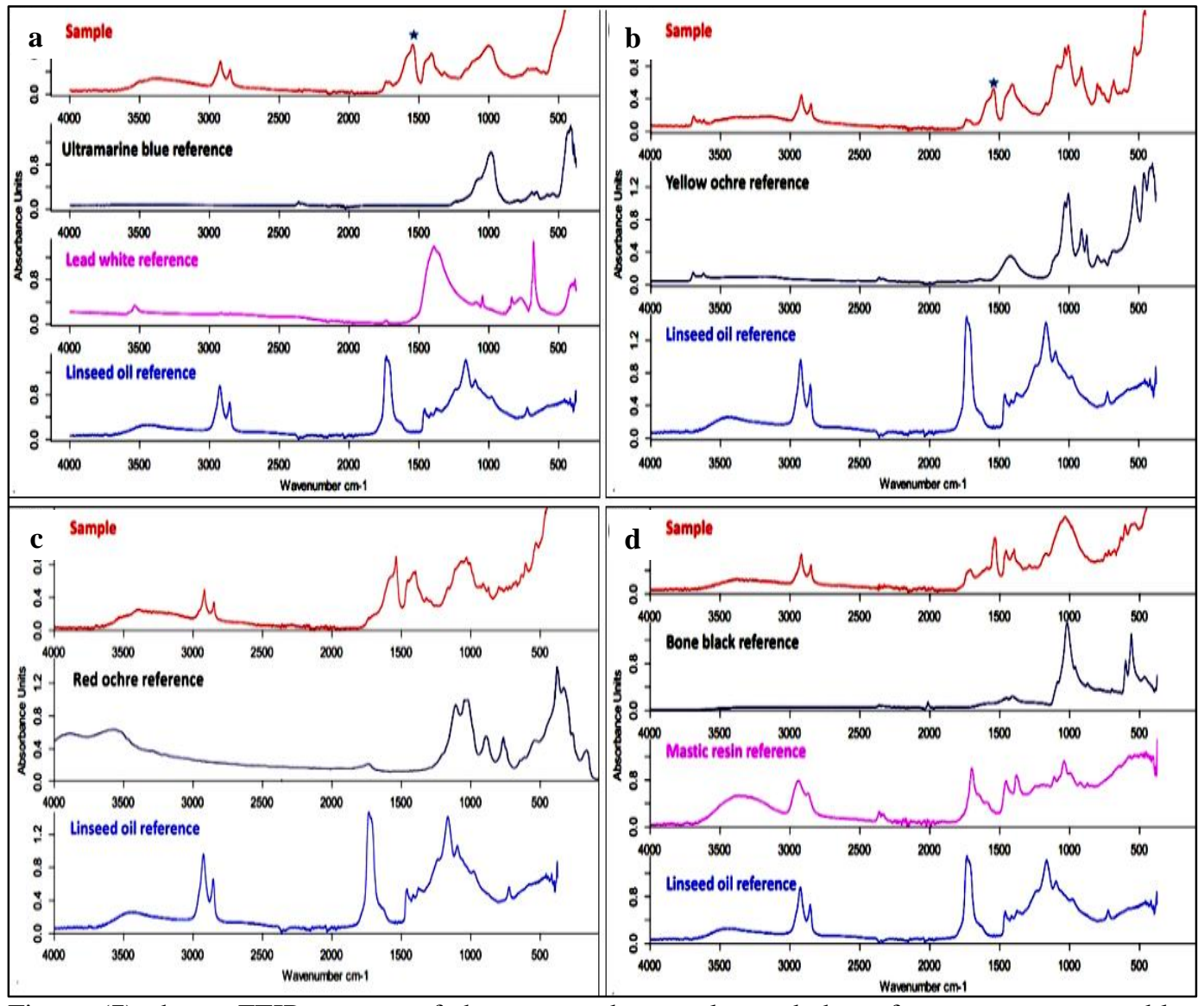

Figure (7) shows FTIR spectra of the case-study samples and the references spectra, $\underline{\mathbf{a}}$. blue sample, $\underline{\mathbf{b}}$. yellow sample, $\underline{\mathbf{c}}$. reddish brown sample, $\underline{\mathbf{d}}$. black sample spectrum 


\subsection{GC-FID}

The selected spectrum of the GC analyses, fig. (8), for the four macrosamples show using linseed oil as a binding media in the pigments of the painting. The oleaginous binding media is indicated by the saturated monocarboxylic acids, palmitic and stearic acids. Moreover, the ratio of palmitic acid to stearic acid (P/S) characterizes the drying oils in ancient paintings. This $\mathrm{P} / \mathrm{S}$ approach can determine the well-known paint media like walnut oil, linseed oil and poppy seed oil $[9,33]$. By comparing the $\mathrm{P} / \mathrm{S}$ ratio of the investigated sample (1.6) to the reference ratio of binding media in other pieces of literature, we may suggest that linseed oil (which $\mathrm{P} / \mathrm{S}$ ratio is $1.9 \pm 0.5$ ) is the drying oil in the case-study painting [34-36].

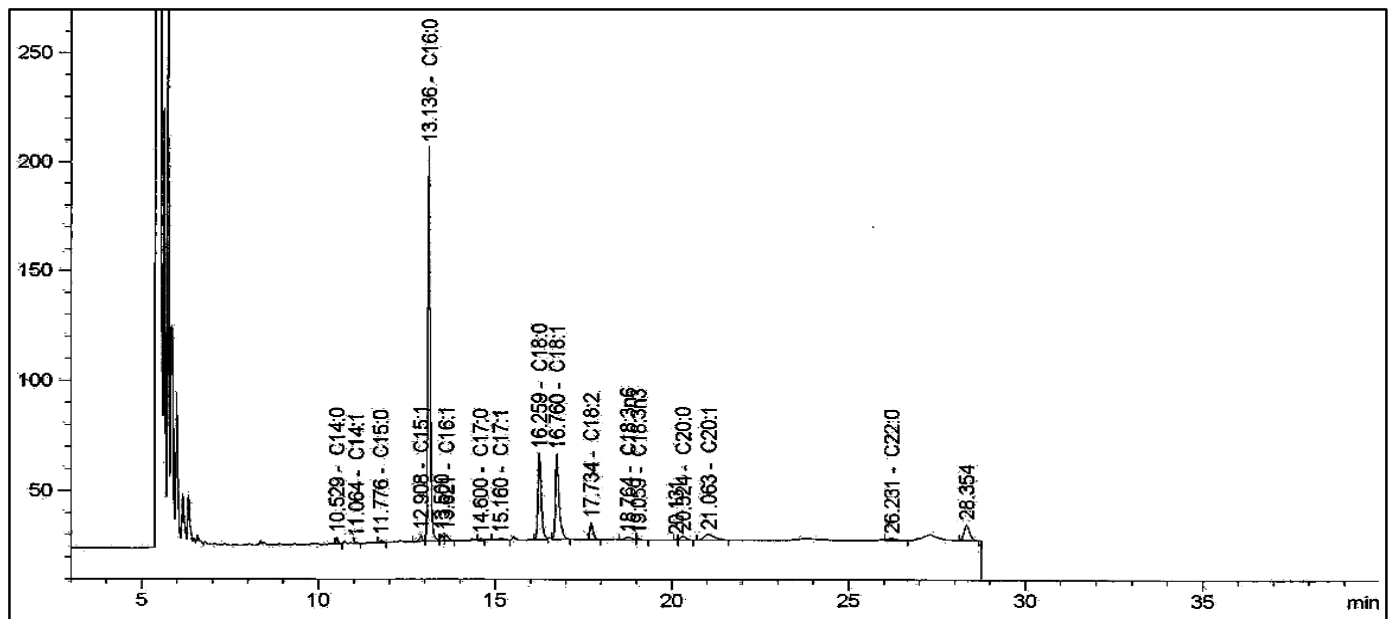

Figure (8) shows the results of GC-FID analysis of the binding media (linseed oil)

\section{Discussion}

The results of MA-XRF analysis of the macro-samples report nine elements: $\mathrm{Ca}, \mathrm{Cr}, \mathrm{Fe}, \mathrm{Zn}, \mathrm{Ba}, \mathrm{Pb}, \mathrm{Sr}, \mathrm{K}$, and $\mathrm{Cu}$. Due to the higher ability of the EDX unit to detect more elements than the MA$\mathrm{XRF}$, the results of the EDX spectra and maps of the same samples show more elements. This is one of the MA-XRF's well-known limitations [16,28]. While MA-XRF detected only 9 elements, EDX detected 16 (i.e. C, O, Mg, Al, Si, P, S, $\mathrm{Cl}, \mathrm{K}, \mathrm{Ca}, \mathrm{Cr}, \mathrm{Fe}, \mathrm{Zn}, \mathrm{Sr}, \mathrm{Cd}$, and $\mathrm{Ba}$ ) in the blue sample. The data obtained by the EDX help promote the interpretation and expect-ation of the pigments in each sample $[37,38]$. Based on the results of the MA-XRF and EDX, the presence of $\mathrm{Pb}$ suggests Hydrocerussite $\left(\mathrm{Pb}_{3}\left(\mathrm{CO}_{3}\right)_{2}\right.$ $\left.(\mathrm{OH})_{2}\right)$, while $\mathrm{Ca}$, and some other elements like $\mathrm{Na}, \mathrm{S}, \mathrm{Si}$ and $\mathrm{Al}$ may refer to Ultramarine (lazurite) $\quad(\mathrm{Na}, \mathrm{Ca})_{8}\left(\mathrm{AlSiO}_{4}\right)_{6}$ $\left(\mathrm{SO}_{4}, \mathrm{~S}, \mathrm{Cl}\right)_{2}$ [39]. Moreover, $\mathrm{Ca}$ with other elements, such as $\mathrm{P}$ and $\mathrm{S}$ refer to the bone black pigment [40]. $\mathrm{P}, \mathrm{Na}, \mathrm{S}, \mathrm{Si}$, and $\mathrm{Al}$ are undetectable by the MA-XRF [16,
27,41]. Fe may refer to the reddish brown and yellow iron oxides $\left(\mathrm{Fe}_{2} \mathrm{O}_{3} /\right.$ $\mathrm{Fe}_{2} \mathrm{O}_{3} \cdot \mathrm{H}_{2} \mathrm{O}$ ) used as pigments in the reddish brown and yellow paint layers in different shadows $[7,42]$. The strong signal of $\mathrm{Ba}$ may refer to Barite (BaSO4) and $\mathrm{Zn}$ to Zincite $(\mathrm{ZnO})$ that were used in the white ground layer [43,44], especially Barite which has a strong signal of $\mathrm{Ba}$ in the colorless white area in the right lower edge of the blue sample. Other elements like $\mathrm{Sr}, \mathrm{Cr}, \mathrm{K}$, and $\mathrm{Cu}$ may refer to some impurities either in the coloring materials or in the ground layer, or even some kind of outsider dirt that polluted the painting over time, especially $\mathrm{Cu}$ which has not been detected by EDX and $\mathrm{K}$ which has been detected only in the blue sample. Sr in the blue sample is detected only in the ground layer. It is normally detected as an impurity with Barite $\left(\mathrm{BaSO}_{4}\right)$ in the ground layer [43]. Moreover, it is not detected in the yellow sample, while it appears in both the 
reddish brown and black samples. This may suggests the incompatibility of the ingredients used in brushing the ground layer, which may vary from one area to another in the paining, or it may show that the blue and yellow pigment layers are too thick. Consequently, the white ground layers are undetectable. It is also observed that MA-XRF notably detected nine chemical elements in all samples. This may be due to the many layers of different colors the painter had repeatedly applied over time. This result may interpret why the painter spent four years to implement that unique painting. $\mathrm{Na}$ in the ultramarine pigment is not detected in the blue sample. It is not easily detectable either by EDX or MA-XRF. Furthe- rmore, the ultramarine has variant formulas that usually differ from a refer-ence to other. The presence of $\mathrm{Cl}$, in the presence of the probably undetected Na, may refer to a small amount of Sodium chloride which might be undetected neither by MAXRF because of its limitations, nor XRD because of some expected differences between the two samples according to the difference of the object areas where both samples were collected. Moreover, other detected elements like $\mathrm{Mg}, \mathrm{K}, \mathrm{Cr}$, and $\mathrm{Sr}$ may refer to some traces of earth minerals as impurities either the coloring pigments or the ground layer or they may pollute the painting object as outsider dirt, tab. (3) [45-49].

Table (3) the scanned samples, the EDX detected elements and the used chemical compounds

\begin{tabular}{|c|c|c|}
\hline Sample color & EDX detected elements & Used chemical compounds \\
\hline Blue & $\begin{array}{l}\mathrm{C}, \mathrm{O}, \mathrm{Mg}, \mathrm{Al}, \mathrm{Si}, \mathrm{P}, \mathrm{S}, \mathrm{Cl} \\
\mathrm{K}, \mathrm{Ca}, \mathrm{Cr}, \mathrm{Fe}, \mathrm{Zn}, \mathrm{Sr}, \mathrm{Cd} \\
\mathrm{Ba}\end{array}$ & $\begin{array}{l}\text { Ultramarine }(\mathrm{Na}, \mathrm{Ca})_{8}(\mathrm{AlSiO})_{6}\left(\mathrm{SO}_{4}, \mathrm{~S}, \mathrm{Cl}\right)_{2} \text {. Hydro- } \\
\text { cerussite }\left(\mathrm{Pb}_{3}\left(\mathrm{CO}_{3}\right)_{2}(\mathrm{OH})_{2}\right)-\text { Barite }\left(\mathrm{BaSO}_{4}\right)- \\
\text { Zincite }(\mathrm{ZnO})-\text { Sphalerite }(\mathrm{ZnS})\end{array}$ \\
\hline Yellow & $\begin{array}{l}\mathrm{C}, \mathrm{O}, \mathrm{Al}, \mathrm{Si}, \mathrm{Ca}, \mathrm{Cr}, \mathrm{Fe} \\
\mathrm{Zn}, \mathrm{Cd}, \mathrm{Ba}, \mathrm{Pb}\end{array}$ & $\begin{array}{l}\text { Yellow ocher }\left(\mathrm{Fe}_{2} \mathrm{O}_{3} \cdot \mathrm{H}_{2} \mathrm{O}\right) \text { - Hydrocerussite }\left(\mathrm{Pb}_{3}\left(\mathrm{CO}_{3}\right)_{2}\right. \\
\left.(\mathrm{OH})_{2}\right) \text { - Zinc white }(\mathrm{ZnO}) \text { - Barite }\left(\mathrm{BaSO}_{4}\right)\end{array}$ \\
\hline $\begin{array}{l}\text { Reddish } \\
\text { brown }\end{array}$ & $\begin{array}{l}\mathrm{C}, \mathrm{O}, \mathrm{Mg}, \mathrm{Al}, \mathrm{Si}, \mathrm{P}, \mathrm{S}, \mathrm{Cl} \\
\mathrm{K}, \mathrm{Ca}, \mathrm{Cr}, \mathrm{Fe}, \mathrm{Zn}, \mathrm{Ba}, \mathrm{Pb}\end{array}$ & $\begin{array}{l}\text { Zinc white }(\mathrm{ZnO})-\text { Red ocher }\left(\mathrm{Fe}_{2} \mathrm{O}_{3)}-\text { Quartz }\right. \\
\left(\mathrm{SiO}_{2}\right) \text { - Sphalerite }(\mathrm{ZnS}) \text { - Barite }\left(\mathrm{BaSO}_{4}\right)\end{array}$ \\
\hline Black & $\begin{array}{l}\mathrm{C}, \mathrm{O}, \mathrm{Mg}, \mathrm{Al}, \mathrm{Si}, \mathrm{P}, \mathrm{Cl}, \mathrm{K} \\
\mathrm{Ca}, \mathrm{Cr}, \mathrm{Fe}, \mathrm{Zn}, \mathrm{Ba}, \mathrm{Pb}\end{array}$ & $\begin{array}{l}\text { Hydrocerussite }\left(\mathrm{Pb}_{3}\left(\mathrm{CO}_{3}\right)_{2}(\mathrm{OH})_{2}\right)-\text { Zinc white } \\
(\mathrm{ZnO}) \text { - Barite }\left(\mathrm{BaSO}_{4}\right) \text { - Graphite }(\mathrm{C}) \text { - Bone black } \\
\left(\mathrm{C}, \mathrm{Ca}_{5}(\mathrm{OH})\left(\mathrm{PO}_{4}\right)_{3}\right)\end{array}$ \\
\hline
\end{tabular}

The XRD results in tab. (2) generally confirm the suggested used materials detected by MA-XRF and EDX in tab. (3). They confirm that the blue, yellow, red, and black macro-samples contain ultramarine, yellow ocher, red ocher, and graphite, respectively as coloring pigment, in addition to many white materials (i.e. Barite, Zincite, Hydrocerussite, and Sphalerite $\mathrm{ZnS}$ ). These white pigments are probably used either as pigments in lightening the color tones or as components forming the white ground layer. Quartz $\left(\mathrm{SiO}_{2}\right)$ in the ground layer is probably an impurity [50,51]. The results of FTIR also confirm the most used materials detected by MAXRF and EDX. In accordance with the XRD results, this may also except the result of the black sample. The FTIR result of the black sample is incompa- tible, to some extent, with XRD result, which proved that it is graphite [52] because of the difference between the FTIR analyzed spot macro-sample and the XRD analyzed powdered sample. The XRD results confirming the presence of graphite and the FTIR spectrum that attribute to bone black, especially the bands characterizing phosphate group: $v_{3}\left(\mathrm{PO}_{4}\right)^{3-}$ is shown at $1087 \mathrm{~cm}^{-1}$ and $1038 \mathrm{~cm}^{-1}, v_{1}\left(\mathrm{PO}_{4}\right)^{3-}$ is shown at $875 \mathrm{~cm}^{-1}$ and $962 \mathrm{~cm}^{-1}, v_{4}\left(\mathrm{PO}_{4}\right)^{3-}$ is shown at $630 \mathrm{~cm}^{-1}, 604 \mathrm{~cm}^{-1}, 567$ $\mathrm{cm}^{-1}$, and $v_{2}\left(\mathrm{PO}_{4}\right)^{3-}$ is shown at 469 $\mathrm{cm}^{-1}$. [51] cannot be ignored. These results were notably confirmed by the EDX results which include $\mathrm{C}, \mathrm{Ca}$, and $\mathrm{P}$; the main ingredients in bone black. Sometimes graphite and bone black represent confusion between XRD and EDX results [53] because both 
materials are obtained. Therefore, it is important to use additional techniques like EDX and FTIR along with XRD to get complete information about the investigated samples $[29,53]$. The SM results may provide an additional interpretation for the confusion of the results of the different techniques. They confirm the multilayers used in the case-study object. Therefore, the difference in the results of the same samples may be attributed to the difference in the components of each sample even if they all are collected from the same area in the object. In other words, it is the same area in the object, but it includes different components in different layers.

\section{Conclusion}

The present study is a valuable insight into the painting materials and techniques of "Lady on a Roof", a unique oil painting by the well-known Egyptian painter Mahmoud Sa'id, which has experienced deterioration. The utilized techniques reported the multilayers technique used by the painter over the four years of the painting's implementation. Therefore, the elemental distribution mapping of the scanned samples by MA-XRF almost revealed the same elements in all samples. It was confirmed by EDX and XRD. Ultramarine, yellow ochre, red ochre, as well as bone black and graphite were reported as coloring pigments in the investigated blue, yellow, reddish brown and black samples, respectively. Moreover, Zincite (ZnO), Lazurite $(\mathrm{Na}, \mathrm{Ca})_{8}\left(\mathrm{AlSiO}_{4}\right)_{6}\left(\mathrm{SO}_{4}, \mathrm{~S}, \mathrm{Cl}\right)_{2}$, Barite $\left(\mathrm{BaSO}_{4}\right)$, Hydrocerussite $\left(\mathrm{Pb}_{3}\left(\mathrm{CO}_{3}\right)_{2}(\mathrm{OH})_{2}\right.$, Sphalerite $(\mathrm{ZnS})$ and Quartz $\left(\mathrm{SiO}_{2}\right)$ were detected in the painting and the ground layers. Linseed oil was proved to be used as binding media. Hydrocerussite mixed with zinc oxide and barite was used as a white ground layer. A glued linen textile was utilized as a canvas. Finally, the investigations and analysis techniques showed how much the casestudy painting experienced deterioration phenomena e.g. cracks, cleavages, fragility, brittleness and fault ancient restorations, including inpainting and patching. Accordingly, the painting requires utmost new re-treatment and preservation. In Egypt, and due to the lack of the most non-invasive techniques in the investigation and analysis of the cultural heritage objects, the author was obliged to utilize macro-sampling of the painting and to implement the required non-destructive and non-invasive analysis abroad only on the collected macro-samples. Furthermore, it is not possible to move the heritage objects from the museum in Egypt for studying. Thus, the study recommends establishing a hightech non-invasive investigation lab in Egypt and facilitating the movement of the heritage objects from the Egyptian museums to this lab for investigation and analysis.

\section{Acknowledgment}

The author would like to thank Prof. Jerzy Łukaszewicz, director of the Interdisciplinary Center for Modern Technologies, UMK in Toruń, Poland and Prof. Piotr Targowski, Faculty of Physics, UMK for the great help they offered in the MA-XRF and SEM-EDX investigations of the case-study samples. The author is also grateful to Dr. Osama Abulkheer, director of the Conservation Center at the Grand Egyptian Museum (GEM$\mathrm{CC})$ for the XRD analysis of the case-study samples. Finally, my deepest thanks go to the director of the Agricultural Museum and the Heritage Collections staff for facilitating the investigation of the case-study painting.

\section{References}

[1] Knut, N. \& Westphal, C. (1999). The restoration of paintings, Köln, Könemann, Cambridge, UK.

[2] Stoner, J. \& Rushfield, R., (2012). The conservation of easel paintings, Routledge, New York.

[3] Hradil, D., Grygar, T., Hradilová, J. \& Bezdićka, P., (2003). Clay and iron oxide pigments in the history of painting, Applied Clay Science, Vol. 22 (5), pp: 223-236.

[4] Costa, T., Ritcher, F., Correia, M., Escorteganha, M., Santiago, A., Gonçalves, S., Spudeit, D., Micke, G. \& Miranda, F., (2016). Multi-technical analysis as a tool to investigate stru- 
ctural species in the "replica" of First Mass in Brazil painting by Sebastião Vieira Fernandes, J. of Molecular Structure, Vol. 1120, (15), pp: 196-204.

[5] Maryse J., (2009). Application of FTIR microscopy to cultural heritage materials, Ph.D., University of Bologna.

[6] Glavcheva, Z., Yancheva, D., Kancheva, Y., Velcheva, E. \& Stamboliyska, B., (2014). Development of FTIR spectra database of reference art and archaeological materials, Bulgarian Chemical Communications, Vol. 46, (A), pp: 164-169.

[7] Genestar, C. \& Pons, C., (2005). Earth pigments in painting: Characterisation and differentiation by means of FTIR spectroscopy and SEMEDS microanalysis, Analytical and Bioanalytical Chemistry, Vol. 382, (2), pp: 269-274.

[8] Stuart, B., Head, K. \& Dredge, P., (2014). Pigments used in ceremonial objects of the Highlands of Papua New Guinea: an infrared spectroscopy study, in: Bridgland, J., (ed.) ICOMCC $17^{\text {th }}$ Triennial Conf. preprints, Melbourne, pp: 15-19

[9] Van den Berg, J., (2002). Analytical chemical studies on traditional linseed oil paints, $\mathrm{PhD}$, Institute for Atomic and Molecular Physics (AMOLF), Amsterdam.

[10] Barnett, J., Miller, S. \& Pearce, E., (2005). Colour and art: A brief history of pigments, Optic \& Laser Technology, Vol. 38, pp: 445-453.

[11] Silva, C., Silva, L., Edwards, H. \& de Oliveira, L., (2006). Diffuse reflection FTIR spectral database of dyes and pigments, Analytical and Bioanalytical Chemistry, Vol. 386, pp: 2183-2191.

[12] Ajò, D., Casellato, U., Fiorin, E. \& Vigato, P., (2004). Ciro Ferri's fres- coes: A study of painting materials and technique by SEM-EDS microscopy, X-ray diffraction, micro FT-IR and photoluminescence spectroscopy, J. of Cultural Heritage, Vol. 5, Issue 4, pp: 333-348.

[13] De Nolf, W., Dik, J., Vandersnickt, G., Wallert, A. \& Janssens, K., (2011). High energy X-ray powder diffraction for the imaging of (hidden) paintings, J. of Analytical Atomic Spectrometry, Vol. 26 (5), pp: 910-916.

[14] Alfeld, M., Siddons, D., Janssens, K., Dik, J., Woll, A., Kirkham, R. \& van de Wetering, E., (2012). Visualizing the $17^{\text {th }}$ century under painting in portrait of an old man by Rembrandt van Rijn using synchrotron-based scanning macro-XRF, Applied Physics A, Vol. 111, (1), pp: 157-164.

[15] Van der Snickt, G., Martins, A., Delaney, J., Janssens, K., Zeibel, J., Dufy, M., McGlinchey, C., Van Driel, B. \& Dik, J., (2016). Exploring a hidden painting below the surface of René Magritte's le portrait. Appl Spectrosc, Vol. 70 (1), pp: 57-67.

[16] Alfeld, M., Janssens, K., Dik, J., de Nolf, W. \& van der Snickt, G., (2011). Optimization of mobile scanning macro-XRF systems for the in situ investigation of historical paintings, J. Anal At Spectrom, Vol. 26, pp: 899-909.

[17] Izzo, F., Ferriani, B., Van den Berg, K., Keulen, H. \& Zendri, E., (2014) $20^{\text {th }}$ century artists' oil paints: The case of the Olii by Lucio Fontana, J. Cult. Herit, Vol. 15, pp: 557-563.

[18] Cruz, A. \& Rego, C., (2014). Scientific study of an $18^{\text {th }}$ century Portuguese painting on canvas and their old restoration: Problems of date and authenticity of the current image, IJCS, Vol. 5, pp: 479-492. 
[19] Calvano, C., van der Werf, I., Palmisano, F. \& Sabbatini, L., (2016). Revealing the composition of organic materials in polychrome works of art: The role of mass spectrometrybased techniques, Analytical and Bioanalytical Chemistry, Vol. 408 (25), pp: 6957-6981.

[20] Bonaduce, I., Ribechini, E., Modugno, F. \& Colombini, M., (2016). Analytical approaches based on gas chromatography mass spectrometry (GC-MS) to study organic materials in artworks and archaeological objects, Top Curr Chem, Vol. 374, (6) pp: 291-327.

[21] De Viguerie, L., Walter, P., Laval, E., Mottin, B., \& Solé, V., (2010). Revealing the sfumato technique of Leonardo da Vinci by X-Ray Fluorescence Spectroscopy, Angew. Chem., Int. Ed., Vol. 49, pp: 61256128.

[22] Miliani, C., Rosi, F., Brunetti, B. \& Sgamellotti, A., (2010). In situ noninvasive study of artworks: The MOLAB multi technique approach, Acc Chem Res, Vol. 15, (43), pp: 728-738.

[23] Abaza, M., (2011). Twentieth century Egyptian art: The private collection of Sherwet Shafei, $1^{\text {st }}$ ed., American University in Cairo Press, Cairo

[24] Goldschmidt, A., (1938). Biographical dictionary of modern Egypt. Lynne Rienner Pub., USA.

[25] Valerie, H. \& Hussam, R., (2017). Mahmoud Said, Skira, Milan.

[26] Van der Snickt, G., Legrand, S., Slama, I., Van Zuien, E., Gruber, G., Van der Stighelen, K., Klaassen, L., Oberthaler, E. \& Janssens, K. (2018). In situ macro X-ray fluorescence (MA-XRF) scanning as a non-invasive tool to probe for subsurface modifications in pain- tings by P.P. Rubens, Microchemical J., Vol. 138, pp: 238-245

[27] Targowski, P., Pronobis-Gajdzis, M., Surmak, A., Iwanicka, M., Kaszewska, E. \& Sylwestrzak, M. (2015). The application of macro$\mathrm{X}$-ray fluorescence and optical coherence tomography for examination of parchment manuscripts, Studies in Conservation, Vol. 60, Supl. (1), pp.167-177.

[28] Alfeld, M., Vaz Pedroso, J., Hommes, M., Van der Snickt, G., Tauber, G., Blaas, J., Haschke, M., Erler, K., Dikand, J. \& Janssens, K., (2013). A mobile instrument for in situ scanning macro-XRF investigation of historical paintings, Analytical Atomic Spectrometry, Vol. 28, (5), pp: 760-767.

[29] Debnath, N. \& Vaidya, S., (2006). Application of X-ray diffraction technique for characterization of pigments and control of paints quality, Progress in Organic Coatings, Vol. 56, pp: 159-168.

[30] White, R. \& Pilc, J., (1996). Analyses of Paint Media, in: Davies, D. \& Green, J., (eds.) National Gallery Technical Bulletin, Vol. 17, pp: 91-103.

[31] Colombini, M., Modugno, F., Giacomelli, M. \& Francesconi, S., (1999) Characterisation of proteinaceous binders and drying oils in wall painting samples by gas chromatography-mass spectrumetry, $J$. of Chromatography A, Vol. 846, pp: 113-124.

[32] Vahur, S., Teearu, A., Peets, P., Joosu, L., and Leito, I., (2016). ATR-FT-IR spectral collection of conservation materials in the extended region of $4000-80 \mathrm{~cm}^{-1}$, Anal Bioanal Chem, Vol. 408, pp: 3373-3379.

[33] Mills, J., and White, R., (1994). The organic chemistry of museum obj- 
ects, $2^{\text {nd }}$ ed., Arts and archaeology, Oxford, Butterworth-Heinmann Ltd.

[34] Schilling, M. \& Khaijan, H., (1996). Gas chromatographic determination of fatty acid and glycol content of lipids I. The effect of pigments and ageing on the composition of oil paints', in: Bridgland, J., (ed.) ICOM-CC $18^{\text {th }}$ Triennial Conf. preprints Preprints of the $11^{\text {th }}$ Triennial Meeting of the ICOM Committee for Conservation, Edinburgh, Vol. 1, pp: 242-247.

[35] Manzano, E., Rodriguez-Simón, L., Navas, N., Checa-Moreno, R., Romero-Gámez, M. \& CapitanVallvey, L., (2011). Study of the GC-MS determination of the palmitic-stearic acid ratio for the characterisation of drying oil in painting: La Encarnación by Alonso Cano as a case study, Talanta, Vol. 84, pp: 1148-1154.

[36] Elsayed, Y., (2015). Identification of oil media in five canvas paintings at the Agricultural Museum in Egypt, J. of Faculty of Archaeology (Qena), Vol. 10, pp: 60-92.

[37] Zeng, Q., Zhang, G., Zuo, L., (2010). Studies of wall painting fragments from Kaiping Diaolou by SEM/EDX, micro Raman and FT-IR spectroscopy, Microchem. J., Vol. 96, pp: 330-336.

[38] Caruso, F., Martino, D., Saberwyns, S., Van Bos, M., Burgio, L., Di Stefano, C., Peschke, G. \& Caponetti, E., (2014). Micro-analytical identification of the components of varnishes from South Italian historical musical instruments by PLM, ESEM-EDX, micro FTIR, GC-MS, and Py-GC-MS, Microchem. J., Vol. 116, pp: 31-40.

[39] Szökefalvi-Nagy, Z., Demeter, I., Kocsonya, A. \& Kovács, I., (2004) Non-destructive XRF analysis of paintings, Nuclear Instruments and
Methods in Physics Research B, Vol. 226, pp: 53-59

[40] Winter, J. \& Fitzhugh, E., (2007). Pigments based on carbon, in: Berrie, B., (ed.) Artist's Pigments: A Handbook of Their History and Characteristics, Vol. 4, Archetype, London.

[41] Legrand, S., Alfeld, M., Vanmeert, F., De Nolfa, W. \& Janssens, K., (2014). Macroscopic Fourier transform infrared scanning in reflection mode (MA-rFTIR), a new tool for chemical imaging of cultural heritage artefacts in the midinfrared range, Analyst, 139, pp: 2489-2498.

[42] Clark, R., (2002). Pigment identification by spectroscopic means: An arts/science interface. Acad Sci, Vol. 5, pp: 7-20.

[43] Feller, R., (1987). Barium sulfatenatural and synthetic, in: Feller, R., (ed.) Artists' pigments: A handbook of their history and characteristics, Vol. 1, Oxford Univ. Press,USA.

[44] Accorsi, G., Verri, G., Acocella, A., Zerbetto, F., Lerario, G., Gigli, G., Saunders, D. \& Billinge, R., (2014). Imaging, photophysical properties and DFT calculations of manganese blue (barium manganite (VI) sulphate) - a modern pigment, Chem Commun, Vol. 50, pp: 1529715300.

[45] van Eikema Hommes, M., (2002). Discoloration in renaissance and baroque oil paintings. Instructions for painters, theoretical concepts, and scientific data, $\mathrm{PhD}$, Faculty of Humanities, University of Amsterdam, pp: 109-114.

[46] Kalinina, K., Bonaduce, I., Colombini, M. \& Artemieva, I., (2012). An analytical investigation of the painting technique of Italian Renaissance master Lorenzo Lotto, J. of Cultural Heritage, 13, pp: 259-274. 
[47] Zagora, J., (2013). SEM-EDX pigment analysis and multi-analytical study of the ground and paint layers of Francesco Fedrigazzi's painting from Kostanje, CeROArt Online, EGG 3, http://ceroart.revues.org/ 3248. (11-10-2017)

[48] Nepasa, R., \& Všianský, D., (2016). Ultramarine - not just a pigment of traditional folk architecture plasters, Procedia Engineering, Vol. 151, pp: $114-118$.

[49] Saladino, M., Ridolfi, S., Carocci, I., Martino, D., Lombardo, R., Spinella, A., Traina, G., and Caponetti, E., (2017). A multi-analytical non-invasive and micro-invasive approach to canvas oil paintings, general considerations from a specific case, Micro chemical J., Vol. 133, pp: 607-613.

[50] Gambardella, A., Patterson, C., Webb, S. \& Walton, M., (2016). Sulfur K-edge XANES of lazurite: toward determining the provenance of lapis lazuli, Microchemical J., Vol. 125, pp: 299-307.

[51] Daveri, A., Malagodi, M. \& Vagnini, M., (2018). The bone black pigment identification by noninvasive, in situ infrared reflection spectroscopy, Journal of Analytical Methods in Chemistry, Vol. 8, pp: 1-8.

[52] Miliani, C., Rosi, F., Daveri, A. \& Brunetti, B., (2012). Reflection infrared spectroscopy for the noninvasive in situ study of artists' pigments. Appl Phys A, Vol. 106, pp: 295-307.

[53] Brunetti, B., Miliani, C., Rosi, F., Doherty, B., Monico, L., Romani, A. \& Sgamellotti, A., (2016). Noninvasive investigations of paintings by portable instrumentation: The MOLAB experience. Topics in Current Chemistry, 374, 10. 